Special issue of the International Conference on Computational and Experimental Science and Engineering (ICCESEN 2014)

\title{
A Hydrolysis System Design and Analysis for Vehicles with Microprocessor Based and PWM Controlled Card
}

\author{
Y. SARIKAYA, H. APAYDin AND Ş. KiTiş* \\ Dumlupınar Üniversitesi, Simav Meslek Yüksek Okulu, Kütahya, Turkey
}

\begin{abstract}
A hydrolysis system is designed by pulse width modulation controlled card, powered by hydrogen gas, contained of 24 pcs which were $11 \times 11 \times 0.5 \mathrm{~cm}^{3}$ sized, made of $316 \mathrm{~L}$ stainless steel, 6 pcs anode, 6 pcs cathode, 12 pcs neutral and contained of 12 pcs which were $0.8 \times 0.7 \times 0.03 \mathrm{~cm}^{3}$ sized, made of resistant caoutchouc. 1 liter of pure water and $120 \mathrm{~g} \mathrm{KOH}$ were used for hydrolysis system solution. As a result of hydrolysis $4 \mathrm{l} / \mathrm{min}$ hydrogen has appeared. This gas is directly connected to the fuel cell at vehicles. In this way the risks are removed that arise during compression and fuel savings are achieved. Pulse width modulation control card is made with microprocessor. Hydrolysis system is powered by $12 \mathrm{~V}$ DC $1.5 \mathrm{i}$ GLS in $1995,1495 \mathrm{~cm}^{3} / 91.2 \mathrm{cui}, 65 \mathrm{~kW} / 88 \mathrm{PS} / 87 \mathrm{hp}$ (DIN) 5 speed manual power train vehicle used for test drive. Test drive was conducted on $100 \mathrm{~km}$ and results were $10 \mathrm{~A}$ at 1000 $1500 \mathrm{rpm}, 20 \mathrm{~A}$ at $1500-3000 \mathrm{rpm}, 30 \mathrm{~A}$ and over at 3000 and over rpm. So that $35 \%$ saving in fuel consumption was measured. This system will be employable water heater at the next tests.
\end{abstract}

DOI: 10.12693/APhysPolA.128.B-211

PACS: 88.05.Rt, 88.30.E-

\section{Introduction}

The fossil fuels (oil, coal) and natural gas reserves which play important role in the industrial revolution are limited and are also in the greatest environmental problems one of the factors. Alternative fuels revealed need for resources and all these reasons. Hydrogen is this alternative candidate which is unlimited, clean, and efficient [1, 2]. In this study, a hydrolysis system was designed by pulse width modulation (PWM) controlled card. PWM controlled card was designed with PIC16F877A and this card has 3 mosfets for PWM control which were named Q1, Q2, Q3 (Fig. 1) [3-5]. TLP250 is an optocoupler which run to the mosfets. The voltage value is set to the hydrolysis blog, according to the value from the gas potentiometer.

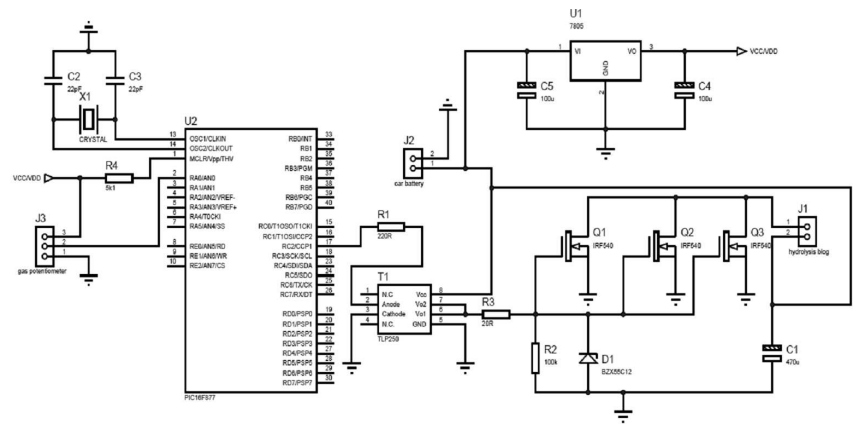

Fig. 1. PWM Control Card with PIC16F877A.

This system is powered by hydrogen gas, contained by $24 \mathrm{pcs}$ which were $11 \times 11 \times 0.5$ sized, made of

*corresponding author; e-mail: sukru.kitis@dpu.edu.tr
316L stainless steel (Fig. 2), 6 pcs anode, 6 pcs cathode, 12 pcs neutral and contained of 12 pcs which were $0.8 \times 0.7 \times 0.3$ sized, made of resistant caoutchouc (Fig. 3) [6].

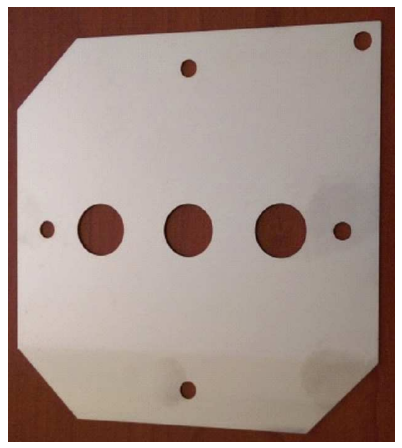

Fig. 2. Stainless steel.

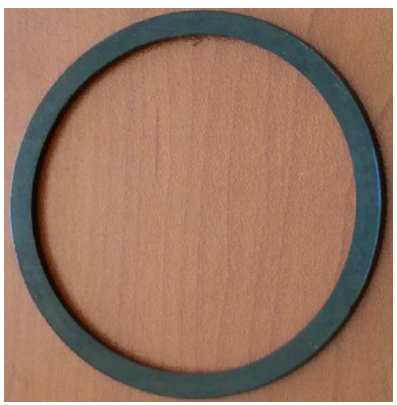

Fig. 3. Resistant caoutchouc.

1 liter of pure water and $120 \mathrm{~g} \mathrm{KOH}$ was used for hydrolysis system solution. As a result of hydrolysis $4 \mathrm{l} / \mathrm{min}$ hydrogen appeared. This gas is directly connected to the fuel cell at vehicles. In this way the risks are removed that arise during compression and fuel savings are achieved (Figs. 4, 5) [7, 8]. 


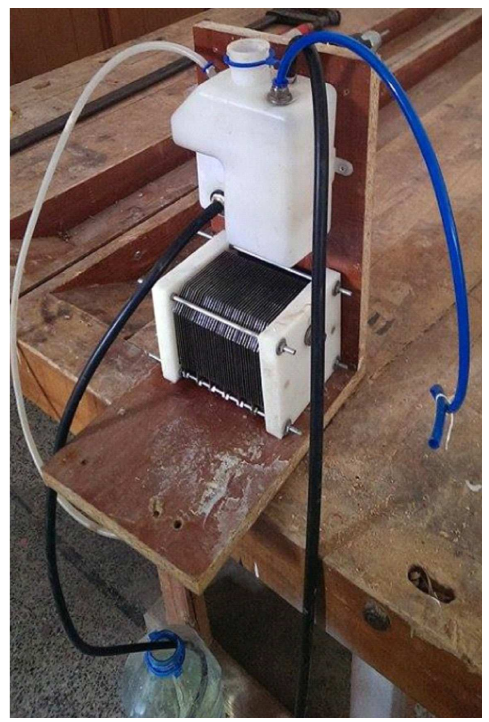

Fig. 4. Hydrolysis system connection.

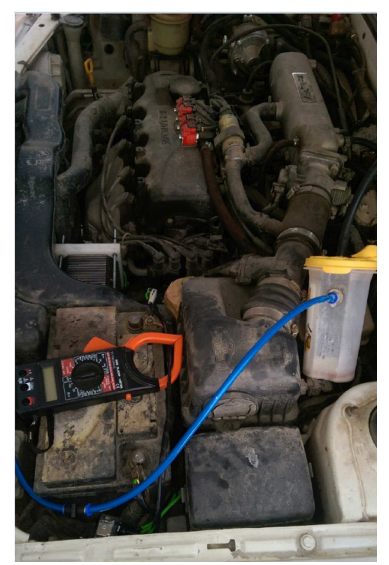

Fig. 5. Hydrolysis blog.

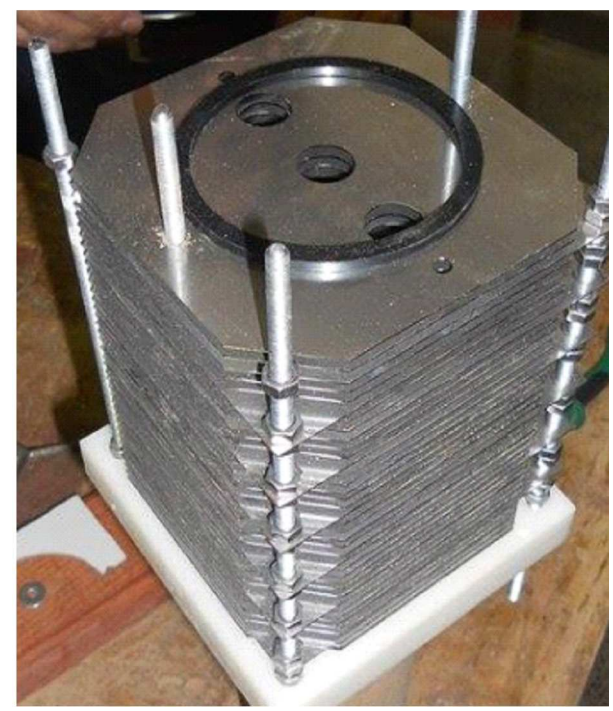

Fig. 6. Hydrolysis system.
Hydrolysis system is powered by $12 \mathrm{~V}$ DC (Fig. 6). 1.5i GLS in 1995, $1495 \mathrm{~cm}^{3} / 91.2$ cui, $65 \mathrm{~kW} / 88 \mathrm{PS} / 87 \mathrm{hp}$ (DIN) 5 speed manual power train vehicle (Hyundai Accent GLS) was used for test drive. Test drive was conducted on $100 \mathrm{~km}$ and results were $10 \mathrm{~A}$ at 1000$1500 \mathrm{rpm}, 20 \mathrm{~A}$ at $1500-3000 \mathrm{rpm}, 30 \mathrm{~A}$ and over at 3000 and over rpm (Table).

TABLE

Table of rpm-current relationship.

\begin{tabular}{c|c}
\hline \hline rpm & Current $[\mathrm{A}]$ \\
\hline $1000-1500$ & $10-12$ \\
$1500-3000$ & $20-22$ \\
$3000-$ over & $30-35$
\end{tabular}

\section{Conclusion}

Test drive was conducted on $100 \mathrm{~km}$ and results were $10 \mathrm{~A}$ at $1000-1500 \mathrm{rpm}, 20 \mathrm{~A}$ at $1500-3000 \mathrm{rpm}$, $30 \mathrm{~A}$ and over at 3000 and over rpm. So that $35 \%$ savings in fuel consumption was measured. This system will be employable water heater at the next tests. In this system 1 liter of pure water and $120 \mathrm{~g} \mathrm{KOH}$ is consumed at $1000 \mathrm{~km}$. KOH more quickly clogged and solidified than $\mathrm{NAOH}$ at high temperature in this system. So that $\mathrm{NAOH}$ was more useful than $\mathrm{KOH}$.

1 liter water is used in the electrolysis process, $2400 \mathrm{l}$ hydrogen gases are generated. 1 liter hydrogen gas is produced per min, $60 \mathrm{l}$ hydrogen gas is produced per hour and these gases are burned per hour, this corresponds to only $32 \mathrm{~g}$ of water [9]. In this system $8 \mathrm{l}$ hydrogen gases are produced per hour and this corresponds to $256 \mathrm{~g}$ of water.

\section{References}

[1] E. Oral, V. Çelik, Hidrojen Yakitli Motor Teknolojisi, Mühendis ve Makine-Cilt:46 p. 540 (in Turkish).

[2] T. Veziroğlu, N.F. Barbir, Hydrogen Energy Technologies, UNIDO, Wien, Austria 1998.

[3] E. Yavuz, Relay Driver with PIC Controller, January 2008, Bilim ve Teknik Dergisi (TÜBİTAK), p. 84 (in Turkish).

[4] C. Hellebuyck, Programming PIC Microcontrollers with Picbasic, Newnes Publications, 2003.

[5] O. Altınbaşak, Microcontroller and PIC Programming, Altaş Yayınevi, 2005 (in Turkish).

[6] F.E. Temelci, M.D. Thesis, YTÜ Fen Bilimleri Enstitüsü, İstanbul 2000 (in Turkish).

[7] M. Güvendiren, T. Öztürk, Hydrogen and Hydrogen Storage as An Energy Source, 2003, p. 523 (in Turkish).

[8] İ. Dipioğlu, M.D. Thesis, Selçuk Üniversitesi Fen Bilimleri Enstitüsü, Konya 1998 (in Turkish).

[9] www.cyberenerji.com. 